\title{
Indonesia stock exchange: Abnormal return
} amid pandemic

JURNFL

INDVRSI EIKONOMI

\author{
Gunistiyo $^{1}$, Jaka Waskito ${ }^{2}$, Yuni Utami ${ }^{3}$ \\ Master of Management, Postgraduate Program at Univesrsitas \\ Pancasakti, Indonesia ${ }^{1}$ \\ Management Department, Univesrsitas Pancasakti, Indonesia ${ }^{2,3}$
}

Received: 11-01-2021 | Revision: 29-01-2001 | Accepted: 27-03-2021

DOI: https://doi.org/10.22219/jiko.v6i01.16056

\begin{abstract}
This study aims to reveal the behavior of investors on the Indonesia Stock Exchange (IDX) before and during (early) the COVID-19 pandemic. This study is an extension of references to understand market reactions in response to future crises. This study is an event study with a time window of 76 trading days before and after the first case was officially announced by the authorities in Indonesia. Taking a sample of stocks included in the Liquid Index (LQ) 45, this study measures the abnormal return and transaction volume during the pre and post-first official announced cases and test the whole data by $\mathrm{t}$-test. The results of data analysis indicate that there is no difference in abnormal returns, but there is a significant difference in transaction volume. These findings indicate that, in general, the Indonesian market is quite efficient, as evident from the absence of different abnormal returns. On the other hand, the market also appears to be cautious in making investment decisions amid uncertainty.
\end{abstract}

Keywords: Abnormal return; transaction volume; COVID-19; IDX

\footnotetext{
Igunistiyosumaryo@gmail.com

2 jakawaskito@gmail.com

3 yuniutami@upstegal.ac.id
} 


\section{Introduction}

In the stock market, information has an important role. The increasingly important role of the stock exchange in economic activity, the more sensitive the stock exchange is to various events around it, directly related to economic issues. The COVID19 pandemic is one of the major events that market players likely never forecasted. As a result, most of the stock markets around the world, including Indonesia were fell. This is due to excessive worry and has a snowball-like impact. However, in the midst of uncertainty, investors rationally try to maximize profits and reduce risks; one way is to understand market behavior (Wardhani, (2014); (Zoraya, 2019).

This research is an event study-based research that examines the market reaction to a certain event, in this case, the COVID-19 pandemic. The market reaction is seen from the difference in abnormal returns and trading volume activity during the predetermined research period. This study contributes to understanding the behaviour of investors in the capital market when facing a crisis so that investors can react rationally and do not take investment actions based on emotions and fears that are not fundamental.

\section{Research Method}

The data used in this study are secondary, and data collection is done by using documentation techniques. Daily closing price data and daily market index (IHSG) are obtained from the IDX database, accessed via the internet. The observation period in this study uses an event period called the event window. This study, using one window, namely the covid-19 pandemic event. Observations were made on the 76 day period before the event occurred and the 76 day period when the event occurred. The estimated period used to determine the expected return is 76 days, calculated from $t-76$. This period is calculated on active trading days on the Indonesia Stock Exchange, 76 days before the event occurs.

Data analysis was carried out by technical analysis; an analysis carried out by estimating stock prices by observing changes in prices in the past (Husnan and Pudjiastuti, 2004). This technical analysis ignores fundamental factors such as company financial data (Hartono, 2008). To see the market reaction, the return is used to measure price changes. Abnormal return exceeds the current return (real return) against the expected return. If the abnormal return for several periods is combined, a cumulative abnormal return (CAR) will be obtained or, in other words, (Capron and Pistre, 2002).

$$
\begin{aligned}
& C A R=\sum A R_{i t} \\
& A R_{i t}=R_{i t}-E\left(R_{i t}\right) \\
& R_{i t}=\frac{P_{i t}-P_{i t-1}}{P_{i t-1}} \\
& E\left(R_{i t}\right)=\alpha_{i}+\beta_{i} R_{m t}+\varepsilon_{i}
\end{aligned}
$$

In where $A R_{i t}$ is $A b n o r m a l$ return of firm $i$ in period $t$; $R_{i t}$ is The return of the of firm $i$ in period $t$; is $E\left(R_{i t}\right)$ is Expected return of firm $i$ in period $t$; $P_{i t}$ is stock price of firm $i$ in period $t ; P_{i t-1}$ is stock price of firm $i$ in period $\mathrm{t}-1 ; \beta_{\mathrm{I}}$ is Beta of the of firm $\mathrm{i} ; \alpha_{\mathrm{i}}$ is constant; $\mathrm{R}_{\mathrm{mt}}$ is market return in period $\mathrm{t}$; and $\varepsilon_{\mathrm{i}}$ is Random error. 
This study tries to include a beta bias correction model to follow up on what has been done by Hartono and Surianto (2000). This causes an unsynchronization between stock returns and the market index, causing the beta calculation to be biased. If used as a basis for analysis, the results will be biased (Hartono and Surianto, 2000; Bartholdy and Riding, 1994). For this reason, this study will perform bias correction in beta before it is used to predict returns. In this case, the model used refers to the research of Hartono and Surianto (2000), namely using the Flower and Rorke models by using one lag period (lag time) and one forward period (lead time) with the following stages:

a. Operate the regression equation betweenRit and Rmt

$$
\mathrm{R}_{\mathrm{it}}=\alpha_{\mathrm{i}}+\beta_{\mathrm{i}}^{-1} \mathrm{R}_{\mathrm{mt}-1}+\beta_{\mathrm{i}}^{0} \mathrm{R}_{\mathrm{mt}}+\beta_{\mathrm{i}}^{+1} \mathrm{R}_{\mathrm{mt}+1}+\varepsilon_{\mathrm{it}}
$$

b. Operate the regression equation to obtain serial correlation between $R_{m t}$ and $R_{m t-1}$

$$
\mathrm{R}_{\mathrm{mt}}=\alpha_{\mathrm{i}}+\rho_{1} \mathrm{R}_{\mathrm{mt}-1}+\varepsilon_{\mathrm{i}} \text {, with } \mathrm{R}_{\mathrm{mt}}=\frac{\mathrm{IHSG}_{\mathrm{t}}-\mathrm{IHSG}_{\mathrm{t}-1}}{\mathrm{IHSG}_{\mathrm{t}-1}}
$$

c. Calculating the weight used

$$
\mathrm{w}=\frac{1+\rho_{1}}{1+2 \rho_{1}}
$$

d. Calculating the corrected beta from stock $\mathrm{i}$ which is the sum of the regression coefficients with the weightening

$$
\beta_{\mathrm{i}}=\mathrm{w} \cdot \beta_{\mathrm{i}}^{-1}+\beta_{\mathrm{i}}^{0}+\mathrm{w} \cdot \beta_{\mathrm{i}}^{+1}
$$

\section{Empirical Result}

The average daily abnormal return 76 days before the Covid 19 pandemic is 0.000618 , the highest is 0.130 , and the lowest is -0.0120 . The average daily abnormal return of 76 days at the time of the Covid 19 pandemic is 0.000066 , the highest was 0.0490, and the lowest was -0.0500 (see Table 1). Meanwhile, the average daily trading volume activity 76 days before the Covid 19 pandemic is 24,997,399 shares, the highest is $70,014,931$ shares, and the lowest is 15,171,220 shares. Furthermore, From Table 1, we also noted that the average daily trading volume activity for 76 days at the Covid 19 pandemic is $51,922,378.4$ shares, the highest was $155,135,907$, and the lowest was 22,991,060 shares.

There was no significant effect of the Covid 19 pandemic on stock abnormal returns in companies listed on the LQ 45 index on IDX in this study. Of course, more indepth studies are needed, for example, by conducting surveys or deep interviews with market players, but this shows that, in general, investors at IDX believe that the impact of the outbreak will not last long. On the other hand, these findings also indicate investor optimism towards the Indonesian economy in particular and the world. Referring to the SARS case, it is known that the weakening trend of the stock market lasts for 6 months. There are expectations of a trend in bear market conditions due to Covid-19 only in the short term (Yang et al., 2020).

There was no significant effect of the Covid 19 pandemic on stock abnormal returns in companies listed on the LQ 45 index on IDX in this study. Of course, more indepth studies are needed, for example, by conducting surveys or deep interviews with 
market players, but this shows that, in general, investors at IDX believe that the impact of the outbreak will not last long. On the other hand, these findings also indicate investor optimism towards the Indonesian economy in particular and the world. Referring to the SARS case, it is known that the weakening trend of the stock market lasts for 6 months. There are expectations of a trend in bear market conditions due to Covid-19 only in the short term (Yang et al., 2020).

Table 1. One Sample Kolmogorov-Smirnov Test

\begin{tabular}{llllll}
\hline & & $\begin{array}{l}\text { Abnormal } \\
\text { return } \\
\text { (before) }\end{array}$ & $\begin{array}{l}\text { Abnormal } \\
\text { return (mid- } \\
\text { post) }\end{array}$ & $\begin{array}{l}\text { Trading volume } \\
\text { activity (before) }\end{array}$ & $\begin{array}{l}\text { Trading } \\
\text { volume activity } \\
\text { (mid-post) }\end{array}$ \\
\hline $\mathrm{N}$ & & 76 & 76 & 76 & 76 \\
Normal Parameter & Mean & -0.000618 & .000066 & 7.3875 & 7.6820 \\
& SD & -.0052408 & .0151476 & .09119 & .16504 \\
Most Extreme & Absolute & .080 & .088 & .094 & .117 \\
& Positive & .058 & .053 & .094 & .117 \\
& Negative & .080 & .088 & .064 & .070 \\
Kolmogorov-Smirnov Z & & .700 & .0765 & .822 & 1.018 \\
& & & & & .251 \\
Asymp. Sig (20tayled) & & .712 & .601 & .508 & \\
& & & & & \\
\hline
\end{tabular}

In particular, strengthening returned more quickly in company stocks with strong fundamentals but are depressed in the short term due to Covid-19. Moreover, this optimism is supported by experience in China as the starting point of the Covid-19 pandemic. History shows the impact of Covid-19 on the stock market only in the short term. The Shanghai Index in China has lost about 12-14\% over the past three months. Starting at the end of March, the stock market in China had reversed and showed a strong trend. As of April 20, the stock market in China rose about 7.2\% from its lowest level.

The Paired-Sample t-Test on the abnormal return between before and during the Covid 19 pandemic, the probability was 0.707 . The probability is more than 0.05 , so it can be concluded that there is no significant difference in abnormal returns for LQ 45 companies listed on the Indonesia Stock Exchange between before and during the Covid 19 pandemic. The results of the Paired-Sample $t$-Test on the trading volume activity between before and during the Covid 19 pandemic had a probability of 0,000 . The probability obtained is less than 0.05 , so it can be concluded that there is a significant difference in trading volume activity. The results of this study are in the line of research conducted by Wardhani (2014), Zoraya (2019), and Wulan (2018), which prove that there is an effect of an event on trading volume activity. Still, it is not by research conducted by Sari (2018), Ramandani (2019) and Farisi (2019) which prove that there is no effect of an event on trading volume activity.

In general, this study shows that even though in the short term the market experiences shocks, investors react to it with a calm and cautious attitude. This shows no difference in abnormal returns, but there is a difference in transaction volume. This 
is very likely because investors are more careful in making transactions in the midst of uncertainty.

\section{Conclusions}

This study reveals that LQ45 investors at IDX did not experience excessive panic selling even though there was a significant fall in the index. This is evidenced by the absence of abnormal returns and differences in transaction volume before and during the COVID-19 pandemic. This finding can reference that the Indonesian stock market is quite efficient so that it is not too over-reactive to allowances. If a major shock occurs, the effects tend to be only in the short term.

\section{References}

Farisi, Gilang Salman Al. 2019. “Analisis Perbedaan Reaksi Bursa Efek Indonesia Sebelum Dan Sesudah Pengumuman Kebijakan Biodiesel 20 (B20) (Studi pada Perusahaan Kelapa Sawit Subsektor Perkebunan Tahun 2018)". Jurnal Administrasi Bisnis (JAB)|Vol. 72 No. 1 Juli 2019. http://administrasibisnis.studentjournal.ub.ac.id

Husnan, Suad. 2013. Dasar-Dasar Teori Portofolio dan Analisis Sekuritas. Yogyakarta : UPP AMP YKPN

Ramandani, Evi Kartika. 2019. “Pengaruh Peristiwa Jatuhnya Pesawat Lion Air Terhadap Abnormal Return Dan Trading Volume Activity". ISOQUANT: Jurnal Ekonomi, Manajemen dan Akuntansi Vol. 3 No. 2 Oktober 2019 Hal: 72-86. http://studentjournal.umpo.ac.id/index.php/isoquant

Sari, Luh Gede Hari Purnama. 2018. "Perbedaan Abnormal Return Sebelum dan Sesudah Pemilihan Umum Gubernur DKI Jakarta Tahun 2017". E-Jurnal Akuntansi Universitas Udayana Vol.24.2.Agustus (2018): 1413-1440. https://doi.org/10.24843/EJA.2018.v24.i02.p22

Wardhani, Laksmi Swastika. 2014. Reaksi Pasar Modal Indonesia Terhadap Peristiwa Pemilihan Gubernur DKI Jakarta Putaran II 2012 (Event Study pada Saham Anggota Indeks Kompas 100). Jurnal Ilmiah Mahasiswa FEB Vol 1, No. 12014. https://jimfeb.ub.ac.id/index.php/jimfeb/article/view/171/134

Wulan, Dewi Cahya. 2018. "Analisis Abnormal Return Dan Trading Volume Activity Terhadap Pengumuman Unusual Market Activity (Studi pada Perusahaan yang Terdaftar dalam Pengumuman Unusual Market Activity di BEI Tahun 2015-2017)”. Jurnal Administrasi Bisnis (JAB)|Vol. 61 No. 1 Agustus 2018. http://administrasibisnis.studentjournal.ub.ac.id

Yang J, Zheng Y, Gou X, Pu K, Chen Z, Guo Q, et al. Prevalence of comorbidities in the novel Wuhan coronavirus (COVID-19) infection: a systematic review and meta-analysis. Int J Infect Dis. 2020; published online March 12. DOI: 10.1016/j.ijid.2020.03.017.

Zoraya, Intan. 2019. “Dampak Pilkada Serentak 27 Juni 2018 Terhadap Abnormal Return Dan Aktivitas Volume Perdagangan Saham DI BEI". Jurnal Riset Manajemen dan Bisnis (JRMB) FakultasEkonomi UNIAT Vol. 5, No 1, November - February 2020: 13 -28. http://jrmb.ejournal-feuniat.net/index.php/JRMB/article/view/355 
